Neth. J. Pl. Path. 91 (1985) 27-44

\title{
Construction and preliminary evaluation of a simulation model of the population dynamics of the potato cyst- nematode Globodera pallida
}

\author{
S.A. WARD ${ }^{1}$, R. RABBINGE ${ }^{1}$ and H. DEN OUDEN ${ }^{2}$ \\ 1 Department of Theoretical Production Ecology, Agricultural University, P.O.B. 430, 6700 \\ AK Wageningen, the Netherlands \\ 2 Research Institute for Plant Protection, P.O.B. 9060,6700 GW Wageningen, the Netherlands
}

Accepted 10 August 1984

\begin{abstract}
A model is constructed to simulate the population dynamics of the potato cyst-nematode, Globodera pallida, and its effect on the growth of the potato. Parameters and rate variables are estimated from published data, and a preliminary evaluation is performed. Despite its simplicity, the model can provide realistic predictions of the real system's behaviour: the predicted relation between initial nematode density and the annual multiplication rate, and the effect of nematode density on tuber yield, are simulated well; the effects of early harvesting are similar to those described in the literature; and the predicted seasonal changes in population structure are in reasonable agreement with field observations. The weaknesses and potentials of the model, and of the dynamic simulation approach, are discussed.
\end{abstract}

Additional keywords: yield loss.

\section{Introduction}

Attempts to control the potato-cyst-nematodes, Globodera rostochiensis (Wollenweber) and G. pallida (Stone) Behrens, have relied on the use of chemical nematicides, resistant cultivars, and crop rotation. In the Netherlands these three methods are used in combination, according to the following set of strict regulations given in the Plant Disease Act of 1973 (Hijink, 1972).

1) Starch-and table potatoes may be grown once every two years, provided the soil is disinfected at least once every four years and at least one potato crop in four years is of a resistant cultivar.

2) If either the soil is disinfected before planting or at least one crop in two uses a resistant variety, potatoes may be grown once in three years.

3) A 1:4 rotation must be used if susceptible cultivars are grown without the use of nematicides.

Recently a number of authors have voiced objections to this scheme, on the grounds of dangers or weaknesses in the practices involved (Mulder, 1978; Van der Weijden, 1981; Groendijk, 1983) or because it discourages the testing of new control methods (Groendijk, 1983).

Neth. J. Pl. Path. 91 (1985) 
These problems have stimulated demands for a more flexible set of regulations, requiring the application of chemicals only if the nematode population density exceeds some threshold (Seinhorst, 1982, Mugniery, 1982; Groendijk, 1983). At densities below this threshold, damage could be limited by combinations of other methods, e.g. resistant cultivars, tolerant cultivars (Trudgill and Cotes, 1983a), crop rotation and the appropriate selection of non-host crops, natural enemies (Goswamy and Rumpenhorst, 1978; Jatala et al., 1979; Kerry, 1980; Franco et al., 1981), treatment of the soil with root extract (Perry et al., 1981) or tree bark (Hoestra and Harshagen, 1981), or early harvesting (Grainger, 1962; Van den Brande and d'Herde, 1964; Mugniery, 1978a,b; 1982; Webley and Jones, 1981; Hoestra, 1983).

Clearly, to optimize the use of these very diverse methods it is necessary to be able to predict their consequences. This requires the construction of a model of the nematode population and its effect on the yield of potatoes. The models proposed in the literature fall into three main groups. Most use empirical relations to describe the final density of eggs as a function of the density before sowing (e.g. Oostenbrink, 1966; Jones, 1966; Jones et al., 1967; Seinhorst, 1967, 1968; Raeuber and Stelter, 1970; Jones and Kempton, 1978; Jones et al., 1978; Jones and Perry, 1978; Mugniery, 1976). Others determine, empirically, the relation between yield and the initial egg density (Seinhorst, 1965, 1983). Two studies, however, describe the timing of certain changes in population structure as a function of accumulated temperature (Mugniery, 1978b; Jones and Perry, 1978).

For a full understanding of the system, and optimization of management practices, an explanatory model is necessary.

This paper presents a dynamic simulation model of the population dynamics of $G$. pallida which is now the most important pest in Dutch potato farming. It begins with a discussion of the dynamic simulation approach. It then describes the relations between the components of the nematode-potato system, before using data from the literature to quantify these relations. Predictions of the model are compared with experimental data and field observations. Finally, the strengths and weaknesses of the model and the approach are discussed.

\section{Systems analysis and dynamic simulation}

The construction of dynamic simulation models proceeds through a number of steps, which can be summarized as follows. (For fuller treatments of the subject see De Wit and Goudriaan, 1978; Berryman and Pienaar, 1974; Rabbinge, 1976; De Wit and Rabbinge, 1979; see also Ferris, 1976, for a nematode simulation.)

First, the system must be defined, and described qualitatively. It is described simply in terms of state variables (i.e., which can be measured at any given instant) and their interactions. At the (artificial) boundaries of the system are the 'driving variables', which influence the behaviour of the system but are not themselves influenced; they may include, for example, the climatic variables affecting an ecosystem. The rates of flow' between the elements of the system are given by the 'rate variables' (e.g. hatch rate, mortality etc.), which are in turn determined by the values of state and driving variables.

The second step is the quantification of the variables, their interrelations, and of their dependence on current conditions. The quantitative model is then expressed as 
a computer programme, which proceeds by continuously up-dating the values of all the state variables, according to the current rate variables.

Finally, the model is evaluated: its predictions are compared with observations of the real system. If, as is usually the case, the predictions differ from observations, the model must be altered. At this point considerable vigilance must be exercised. To avoid changing the process into a very cumbersome curve-fitting exercise, it is important that changes in the model are based on a reappraisal of experimental data (De Wit and Rabbinge, 1979); 'fudging' the model from an explanatory tool to an empirical description; while still possibly a useful management tool it cannot assist in understanding the system.

\section{The nematode potato-model}

\section{A. Description of the system}

The model combines two sub-models: a potato growth model and a nematode population model.

The potato growth model has been constructed by P. Akkermans (Department of Theoretical Production Ecology, Agricultural University, Wageningen) (unpubl.), based on the summary crop growth model SUCROS (Van Keulen et al., 1982). This simulates the dry matter growth of leaves, roots and tubers, as a function of temperature and irradiation.

The second sub-model simulates the changing numbers of individual nematodes in each of seven development classes: mature eggs, eggs stimulated to hatch, free larvae, parasitic 2 nd stage larvae, $3 \mathrm{rd}$ and 4 th stage larvae, adult females, and eggs in dormant cysts.

The structure of the model is represented in a relational diagram in Fig. 1.

\section{B. Quantification}

The parameters and relations determining the rate variables have been estimated from data in the literature. Where data on G. pallida are not available, or when the two species are not distinguished ( $G$. pallida was not recognized as a separate species until 1972), work on G. rostochiensis is used.

a) Standardizing the units of measurement. Potato growth rates are conventionally expressed in $\mathrm{kg} / \mathrm{ha} / \mathrm{day}$, whereas nematode densities are measured in numbers per weight of soil.

Jones et al. (1978) state that if each gram of soil contains one nematode egg, then there are $2.5 \times 10^{9}$ eggs per hectare, in the top $30 \mathrm{~cm}$. Nematodes may be distributed throughout the top $40 \mathrm{~cm}$ (Whitehead, 1977), so the model uses a conversion factor of $3.3 \times 10^{9} \mathrm{~g}$ soil/ha.

b) Soil temperature. Nematode development rates are determined by soil temperature (Jones and Parrott, 1969; Jones, 1975), but the paucity of the available data means that air temperature must sometimes be used as the driving variable. The resulting errors, however, are unlikely to be important, since the main difference between soil and air temperature is that air temperature fluctuates more widely (De Wit and Van Keulen, 1972; Jones, 1974a, 1983).

Neth. J. Pl. Path. 91 (1985) 


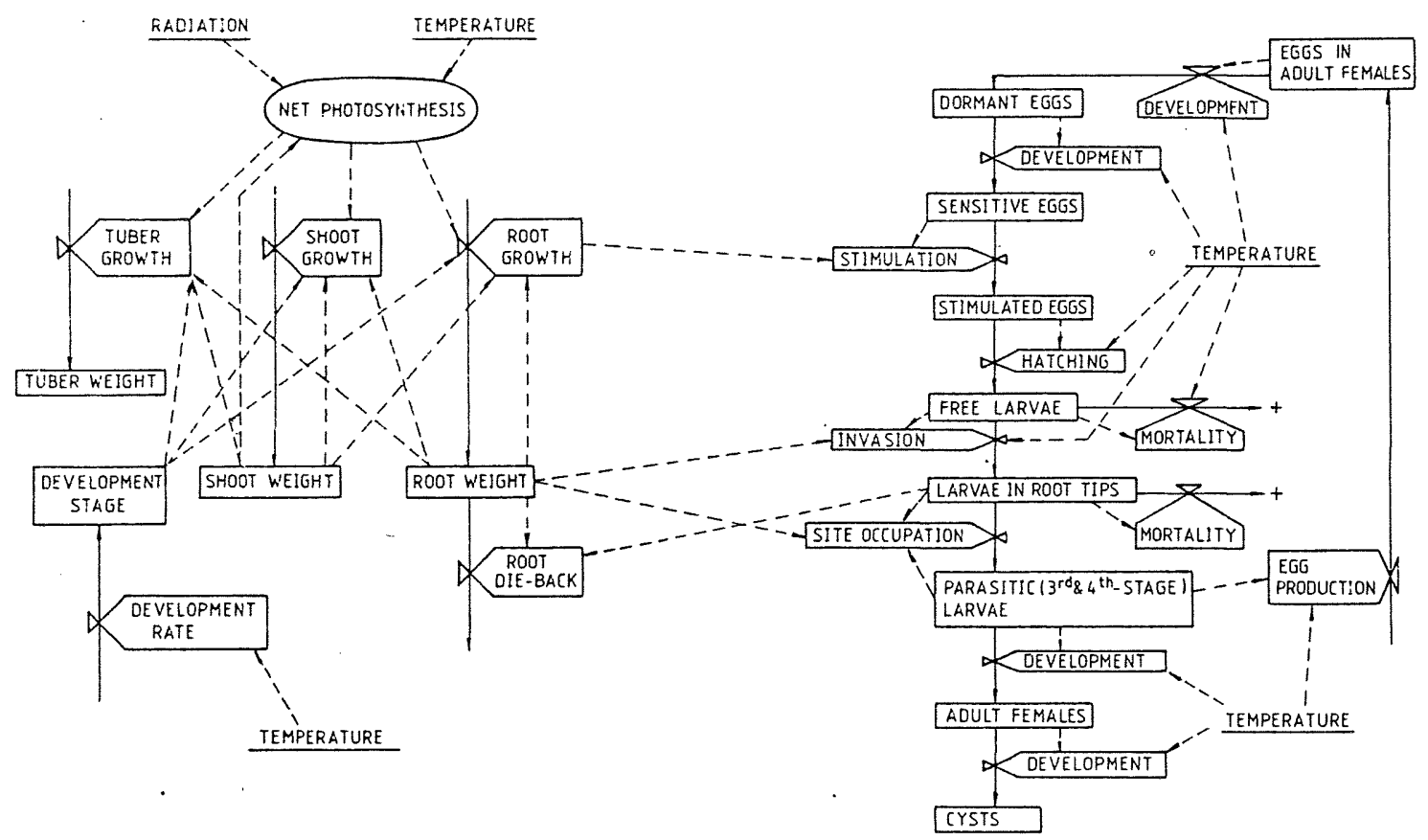

Fig. 1. Relational diagram of growth and development of the potato plant and the cystnematode, Globodera pallida.

Rectangles: state variables; Valve symbols: rate variables; Underlined: driving variables.

$\rightarrow$ : flow of material;..$\rightarrow$ : flow of information.

c) Parameters and temperature relations.

1) Spontaneous hatching in the absence of potatoes. In the absence of host plants, the annual hatch in temperature regions varies between 17 and $53 \%$ (Den Ouden, 1960a; Von Schick and Stelter, 1963; Evans, 1969; Stelter, 1970; Stone et al., 1973). This may depend on temperature (Hague, 1978) and soil moisture (Clarke and Perry, 1977), but is independent of the type of crop grown (Stone et al., 1973). The model assumes an annual hatch of $35 \%$ (Hague, 1978), since no quantitative data are available on these relations.

2) Stimulation to hatch. Eggs of both G. pallida and G. rostochiensis are stimulated to hatch by very brief exposure to potato root diffusate (Forrest and Perry, 1980; Perry and Beane, 1982). The rate at which eggs are stimulated is proportional to the number of eggs present, and to the rate of growth of the roots; it may also vary among potato cultivars (Evans, 1982a, 1983; but see also Turner and Stone, 1981). While, on average, about $80 \%$ of the eggs hatch during the potato growth season (J.W. Seinhorst, pers. comm.), the proportionality constant (relating relative stimulation rate to growth rate) must be estimated from the final root weight of an undamaged crop and the hatch of eggs at very low densities. The model uses a final dry weight of roots, excluding tubers, of $670 \mathrm{~kg} / \mathrm{ha}$ (model output, P. Akkermans, unpubl.) and a $90 \%$ hatch (data of Von Neye et al., 1964). 
3) Emergence of larvae from stimulated eggs. This depends on soil temperature, occurring only between $7{ }^{\circ} \mathrm{C}$ (Foot, 1978) and $32^{\circ} \mathrm{C}$ (Mai, 1952 cited in Franco, 1979); the optimum temperature range is $21-25^{\circ} \mathrm{C}$ (Fenwick, 1951). At $15^{\circ} \mathrm{C}$ the mean time to emergence is 14 days (Den Ouden, 1963).

4) Rate of invasion. The invasion of roots by larvae is assumed to take, on average, one day, provided the soil temperature is between $7{ }^{\circ} \mathrm{C}$ (Foot, 1978) and $30^{\circ} \mathrm{C}$ (Ferris, 1957). No quantitative data yet available on the effects of temperature and soil moisture on this rate.

5) Juvenile sex ratio. Although the proportion of adult females declines with increasing density in the root (Ellenby, 1954; Den Ouden, 1960b; Trudgill, 1967; Ross and Trudgill, 1969; Thornley and Hesling, 1972; Mugniery and Fayet, 1981), this may be caused by selective mortality or recovery (Bridgeman and Kerry, 1980). The model assumes that $50 \%$ of the invading juveniles are female.

6) Rate of occupation of sites in the root. This is calculated as the product of the number of larvae seeking sites and the proportion of sites unoccupied (distribution of larvae within the young root tissue is assumed to be random (Ross and Trudgill, 1969)). Sites are produced at a rate proportional to the rate of growth of the roots, and mature such that giant cell formation becomes impossible (Seinhorst and Den Ouden, 1971). Sites are currently assumed to be available for one day. The number of sites per $\mathrm{kg}$ of new roots is estimated as follows. The maximum number of cysts produced per $\mathrm{cm}$ of root may vary between cultivars (Seinhorst and Den Ouden, 1971). The figure used in the model is 25 per cm: between 22 (Trudgill, 1968, cited in Jones and Parrott, $1969)$ and $30(\mathrm{H}$. den Ouden unpubl. data). With a mean root diameter of approximately $0.5 \mathrm{~mm}$ (Mugniery and Fayet, 1981; H. van Heemst, pers.comm.; although this varies between cultivars - Evans et al., 1977) this gives $1.25 \times 10^{7}$ cysts $/ \mathrm{kg}$ of roots. 7) Development of parasitic larvae. The optimum temperature for development is 24 ${ }^{\circ} \mathrm{C}$ (Ferris, 1957). Here, the time required for a parasitic larva to become an adult is 16-20 days (Chitwood and Buhrer, 1946; J.W. Seinhorst, pers. comm.). The model uses the data of Mugniery (1978a) (Table 1).

8) Maturation of eggs in adult females. Females are assumed to mate immediately after reaching maturity. The time taken for adults to become cysts, and for fertilized

Table 1. Development time of juvenile $G$. pallida at different temperatures.

\begin{tabular}{ll}
\hline $\begin{array}{l}\text { Temperature } \\
\left({ }^{\circ} \mathrm{C}\right)\end{array}$ & $\begin{array}{l}\text { Development time } \\
\text { (days) }\end{array}$ \\
4 & no development \\
9.5 & 52 \\
11.5 & 34.6 \\
15 & 24.5 \\
18 & 19.0 \\
19 & 18.6 \\
24 & 16.5 \\
32 & no development \\
& (Mai and Harrison 1959, \\
& cited in Franco, 1979) \\
\hline
\end{tabular}

Neth. J. Pl. Path. 91 (1985) 
eggs to develop into motile larvae, depends on temperature (Langeslag et al., 1982) (Table 2).

Table 2. Time required for fertilized eggs to develop into motile larvae.

\begin{tabular}{ll}
\hline $\begin{array}{l}\text { Temperature } \\
\left({ }^{\circ} \mathrm{C}\right)\end{array}$ & $\begin{array}{l}\text { Development time } \\
\text { (days) }\end{array}$ \\
5 & no development \\
25 & 14 \\
30 & no development \\
\hline
\end{tabular}

9) Cyst dormancy. Larvae can be stimulated to hatch from very young cysts (Ellenby and Smith, 1967). This initial sensitivity is assumed to last for $10 \%$ of the total cyst maturation time ( $\mathrm{H}$. den Ouden, unpubl. data). The duration of cyst dormancy is temperature-dependent (Ellenby, 1955) (Table 3).

Table 3. Duration of dormancy of G. pallida cysts, in relation to temperature.

\begin{tabular}{ll}
$\begin{array}{l}\text { Temperature } \\
\left({ }^{\circ} \mathrm{C}\right)\end{array}$ & $\begin{array}{l}\text { Maturation time } \\
\text { (months) }\end{array}$ \\
$10^{\circ}$ & no development \\
10 & 18 (from data of Ellen- \\
& by (1955)) \\
33 & 4 \\
32 & development \\
\hline
\end{tabular}

10) The number of eggs per cyst. This is virtually independant of the density of juveniles in the root (Hesling, 1961; Seinhorst, 1968). It is, however, strongly influenced by temperature (Fenwick, 1951; Foot, 1978; Stone and Parrott, 1980). The model uses a growth rate calculated from the temperature-dependent development rate (see Section 7) and the experimental data of Foot (1978) and A. van der Wal. (unpubl.) (Table 4).

Table 4. Relation between temperature and the fecundity of $G$. pallida females.

\begin{tabular}{ll}
\hline $\begin{array}{l}\text { Temperature } \\
\left({ }^{\circ} \mathrm{C}\right)\end{array}$ & Number of eggs \\
& per cyst \\
8 & 225 \\
16 & 250 \\
20 & 250 \\
24 & 50 \\
30 & 50 \\
\hline
\end{tabular}

11) Mortality. a) Cysts. This is assumed to occur only through spontaneous hatching in the absence of hosts (Section 1). b) Free larvae. No data are available on the effect 
of temperature on mortality of juveniles in the soil. The model currently assumes $50 \%$ mortality per week (J.W. Seinhorst, pers. comm.). c) Parasitic larvae. Mortality through failure to occupy sites in the root (Section 6). d) Adult females. Mortality due to death of parts of the root system.

12) The effect of invasion on the potato. The model currently assumes that a section of root dies if it is invaded by twice as many nematodes as it can support. No data are yet available on this aspect, or on the mechanisms resulting in the observed differences in tolerance among potato varieties. The plant then reallocates resources to maintain a (development stage-specific) ratio of shoot weight to living root weight. The ratio of shoot weight to total (living plus necrotic) root weight is thus reduced by invasion injury (Seinhorst and Den Ouden, 1971; Evans, 1982c).

\section{The programme}

The numerical integration uses the rectilinear method (see De Wit and Goudriaan, 1978), with a time-step integration of 0.1 day. The language used in the computer programme is CSMP, Continuous System Modelling Program. A listing of the programme is on request available from the authors.

\section{Preliminary evaluation}

Since the parameters of the model do not all relate to a single set of conditions (i.e., with particular pathotypes and crop variety) precise, statistical comparison of the model with a real system is meaningless. Preliminary comparisons with the system's overall behaviour must, therefore, be couched in rather general therms.

The section considers four aspects of the model's predictions: the relation between initial and final density of eggs in the soil; the effect of harvest date; the effect of initial egg density on the yield of tubers; and the changes in nematode density during the potato growth season.

a) The annual rate of increase. The predicted relation between initial and final densities of eggs is shown in Fig. 2, with, for comparison, the data of Huijsman et al. (1969) and the relation given by Seinhorst (1968). Clearly, the form of the predicted relation is similar to that of the observed relation: there is good qualitative agreement between the model and the real system. Furthermore, the predicted maximum final egg density (170 eggs/g soil), equilibrium density (50 eggs/g soil), and maximum annual multiplication (50x) lie well within the range of values observed in the field (Jones and Perry, 1978; Perry and Jones, 1981).

b) The effect of early harvesting. As described by Mugniery (1978b) and Webley and Jones (1981), harvesting early (90 days after planting) results in a considerable decrease in multiplication rate and equilibrium density, provided the initial density is below 100 eggs/g soil.

c) The effect of nematode density on tuber yield. The predicted relation is presented in Fig. 3. The form of relation derived by Seinhorst (1965) and shown experimentally by Den Ouden (1969) closely resembles that predicted by the model. The density above

Neth. J. Pl. Path. 91 (1985) 


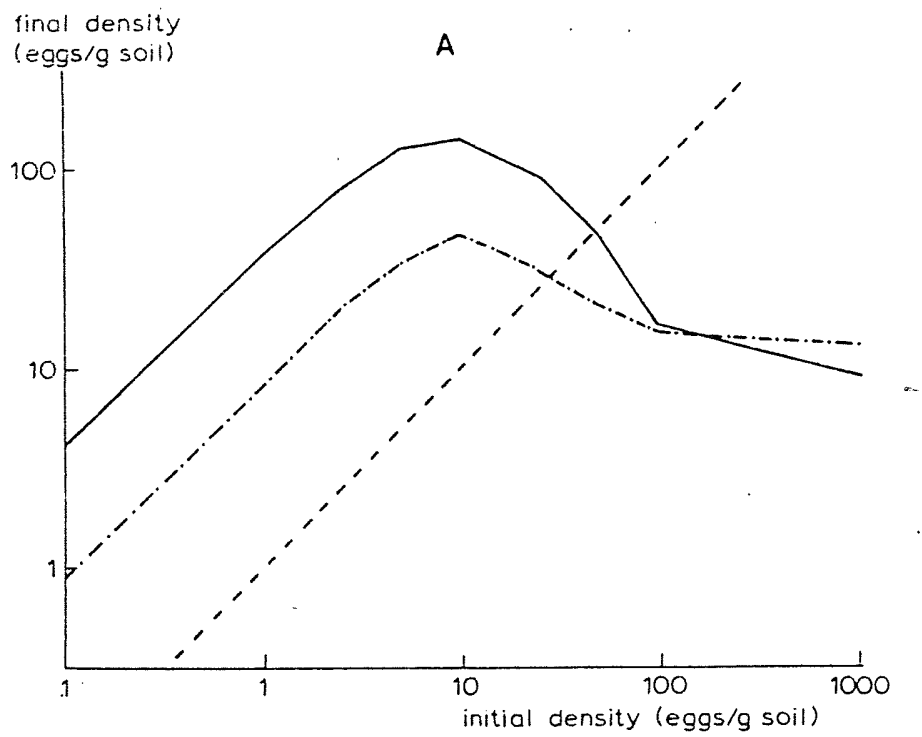

key to symbois

- crop harvested after 120 days

-... " " " 90 days

_. . - final density equal to initial density

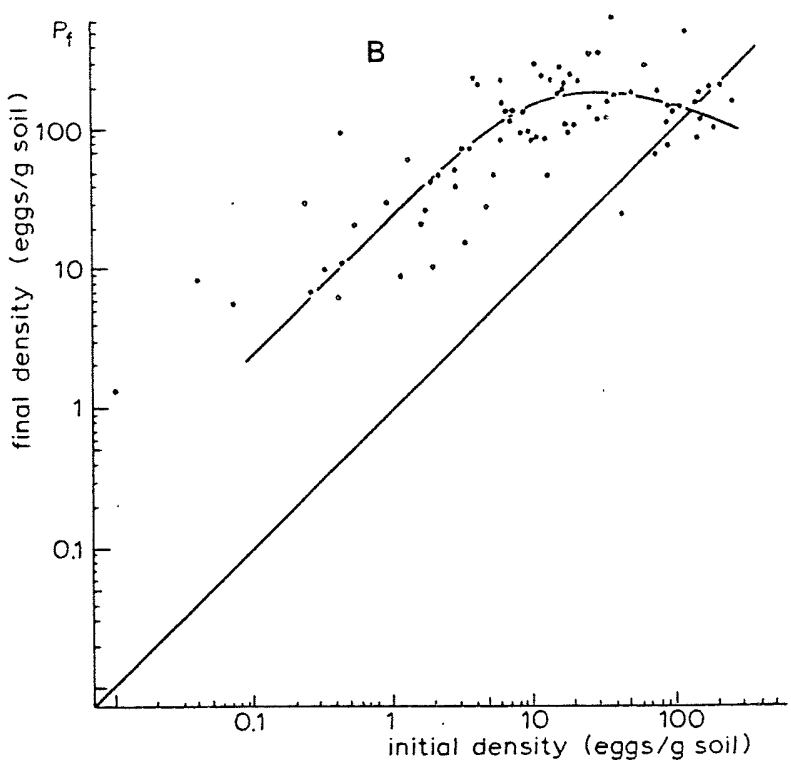

Fig. 2. Relation between initial and final (at time of harvest) densities of G. pallida eggs in soil. a) Simulation results. b) Relation observed by Huijsman et al. (1969). 

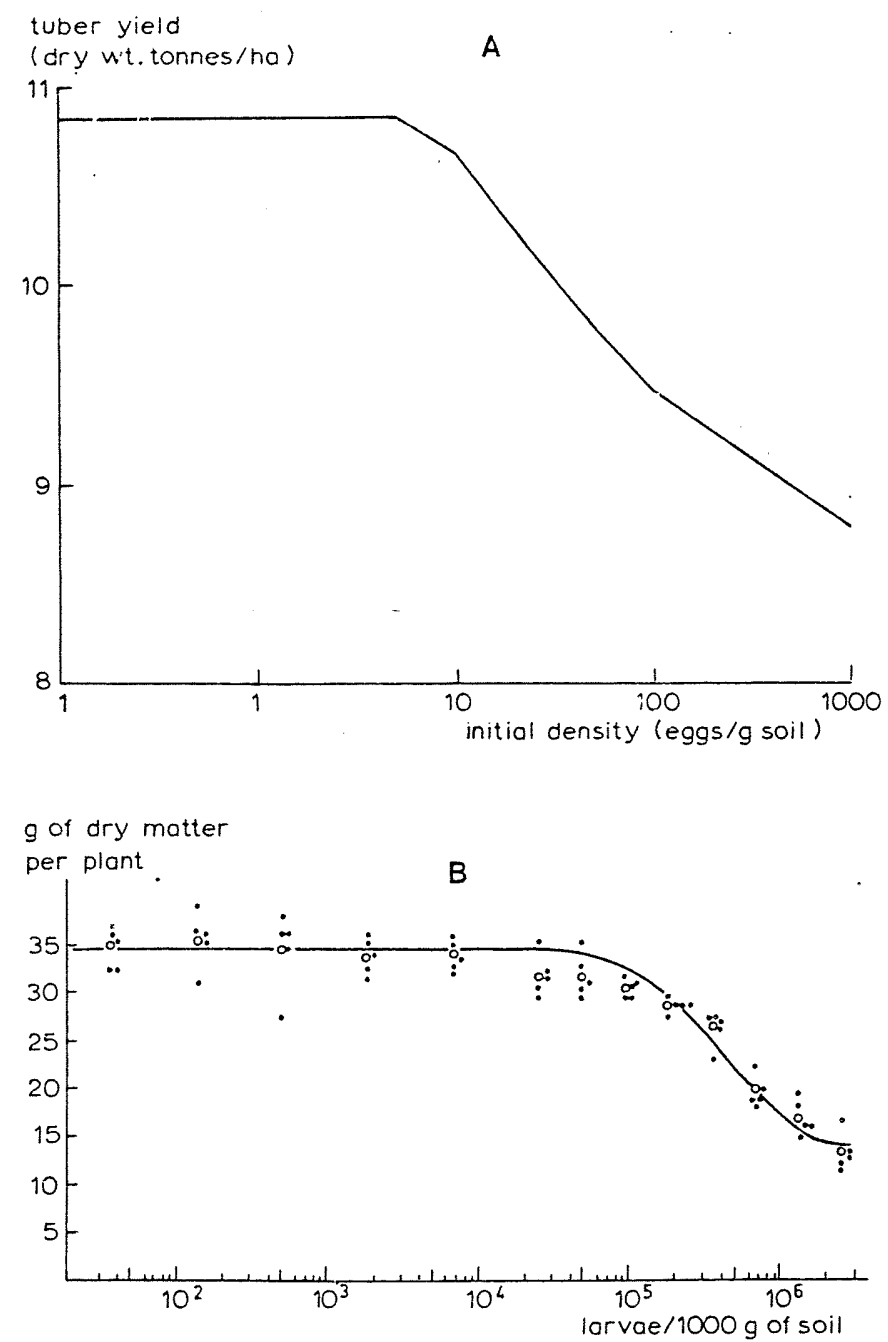

Fig. 3. Effect of initial density of G. pallida eggs on final tuber yield. a) Simulated. b) Observed by: Den Ouden (1969).

. which yield is reduced ( 5 eggs/g soil) is within the range observed in real systems (A. van der Wal, pers. comm.) although this varies considerably among potato cultivars.

d) Seasonal changes in the population. Fig. 4 compares the results of the simulation with the data of Evans (1969) for G. rostochiensis. The times of appearance of the various development classes are described fairly well by the model in its present form, although the different temperature responses of the two species make direct comparison difficult.

The results obtained so far suggest that the model is capable of making fairly realistic predictions of the main features of the system. 
w

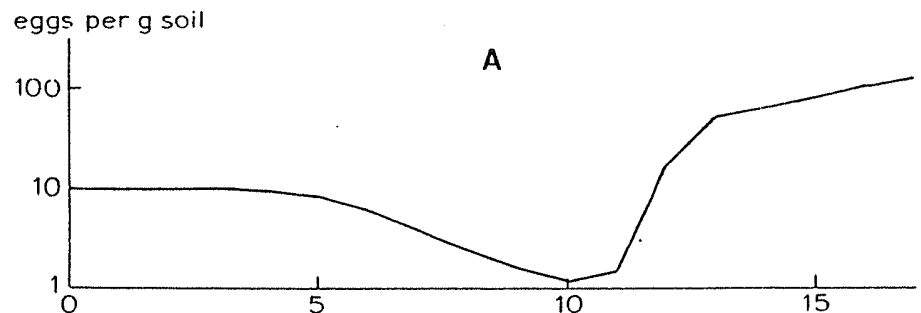

$3^{\text {rd }} \& 4^{\text {th }}$ stage larvae/g dry weight root 10.000

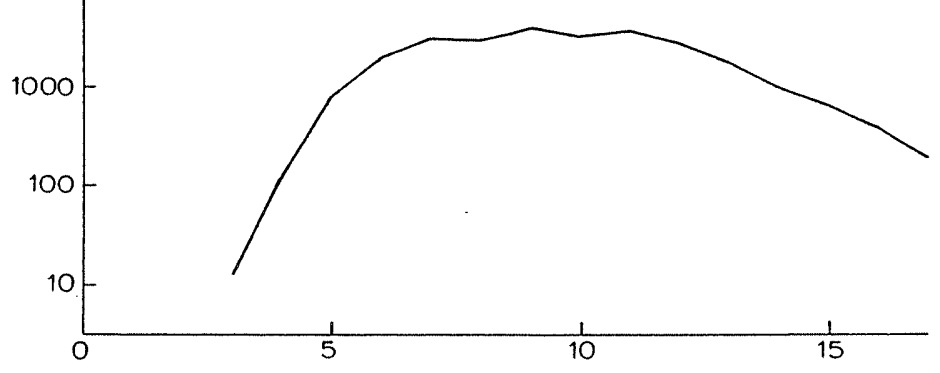

adult females/g dry weight root 10000

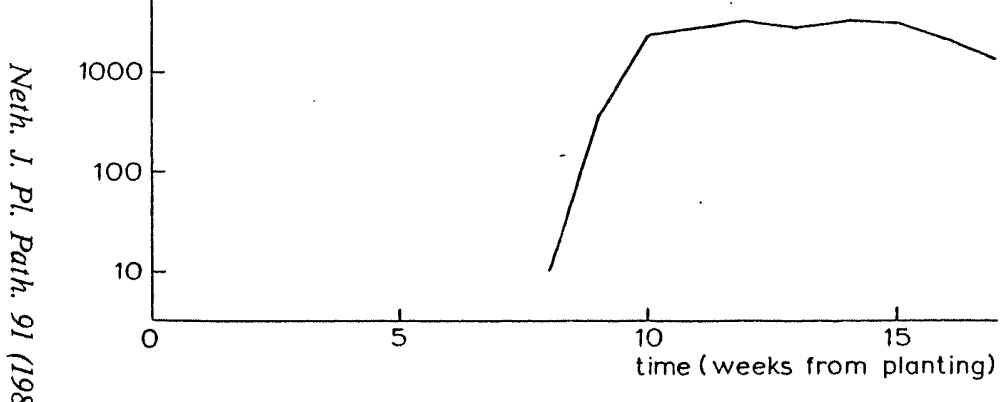

Fig. 4. Seasonal changes in densities of G. pallida eggs, parasitic larvae and adult females. a) Simulated. b) Data on G. rostochiensis (Evans, 1969).
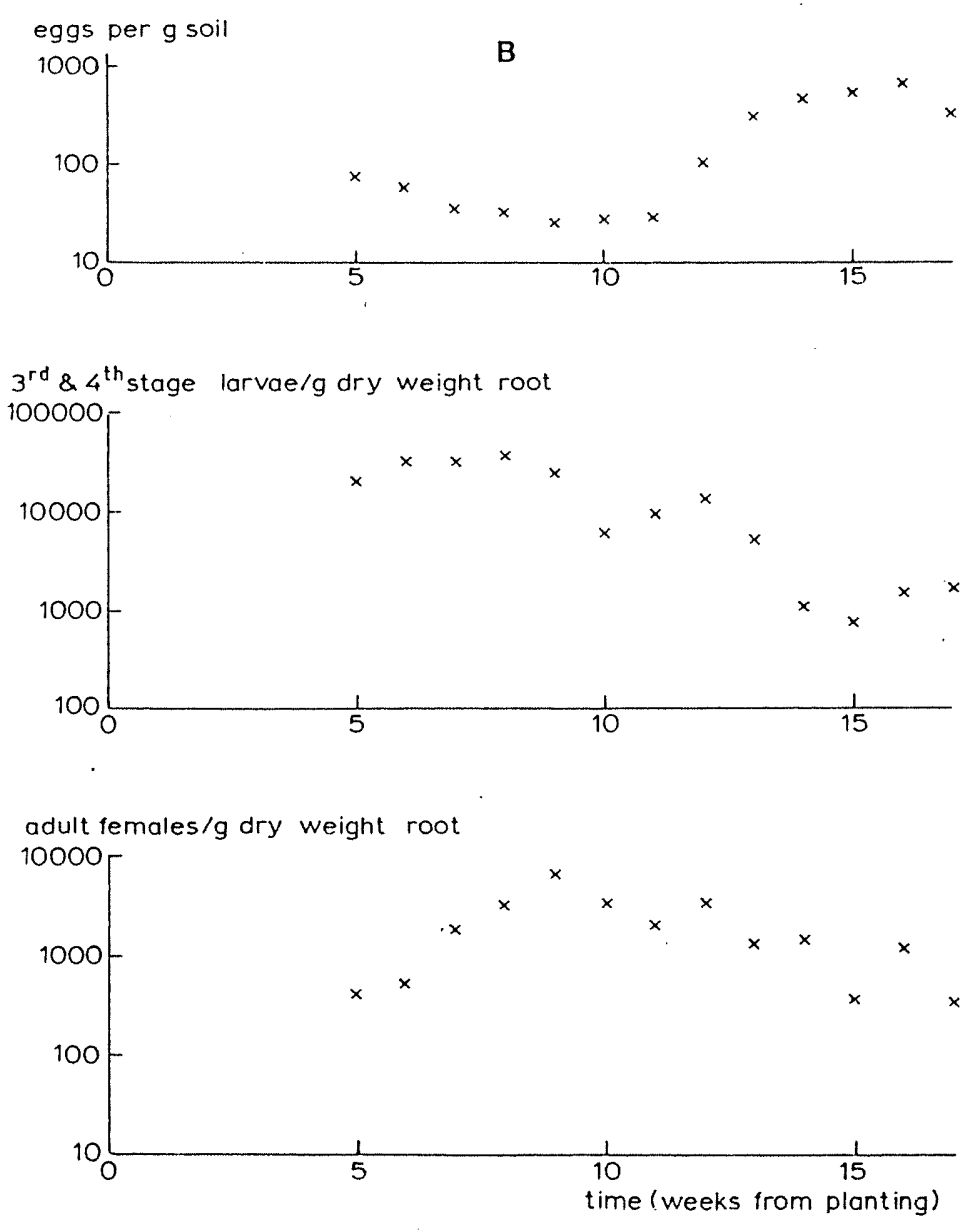


\section{Discussion}

The approach used in the control of potato cyst-nematodes must differ in two fundamental respects from that used against, for example, fungal or insect pests.

First, dispersal of cyst-nematodes is severely limited, so long-term consequences of treatments in a particular part of a field are not masked by immigration from other patches: This means that long-term control measures can be planned, in place of the short-term management used against many other pests.

Secondly, cyst-nematode populations cannot easily be continuously monitored. Instead, estimates must be based on the effect of measurable climatic variables on an initial, measured population.

Efficient, flexible control thus requires the development of simple sampling techniques yielding accurate data on the overall density and the spatial distribution of the population. In addition, the model used in a flexible scheme must accurately simulate the development of local populations over an extended period. They must be 'strategic' models, in contrast to shorter-term 'tactical' models such as the EPIPRE system used in wheat pest management (Onstad et al., 1983).

Despite the simplicity of the model presented above, it has already shown good agreement with several features of the real system. The predicted curves relating initial egg density to final density and tuber yield resemble those in the literature; and the seasonal changes in population structure are simulated fairly well.

The effects of the nematodes' patchy distribution on the damage relation (Seinhorst, 1973) can be modelled simply by simulating each patch separately (Perry and Jones, 1981).

In addition, several other features of the system can be incorporated without structural changes. First, simple parameter changes will allow the model to be used to simulate the population dynamics of $G$. rostochiensis, or of the various pathotypes of the two species (Kort et al., 1977; Stone et al., 1979); and combinations of similar models can simulate competition between the species. Cultivar differences in hatching stimulus (Evans, 1982a, 1983), resistance, or tolerance due to root vigour (Evans, 1982c; Trudgill and Cotes, 1983b) can be included by the alteration of only a few parameters, as can the differences in temperature thresholds between local populations (Ellenby and Smith, 1975; Mugniery, 1978a; Hominick, 1979; Langeslag et al., 1982). Only slightly greater modifications are required to simulate selection for virulance against host resistance (Stone and Turner, 1981). Here, assuming the genefor-gene relation (Jones, 1974b; Parrott, 1979, 1981), simple Mendelian genetics (Jones and Parrott, 1969; Jones et al., 1981) can be incorporated in a sub-model.

There are, however, two important aspects of the system which are not simulated by the model. First, it currently assumes that the growth of the potato is not limited by its water balance. In many cases, however, this assumption is violated (Gandar and Tanner, 1976; Steckel and Gray, 1979; Asfary et al., 1983). Two mechanisms operate here: photosynthesis is closely related to transpiration (De Wit, 1978; Allen and Scott, 1980); and water uptake determines the allocation of dry matter to the various parts of the plant (Brouwer, 1962; El Nadi et al., 1969; Davidson, 1969a,b; De Wit et al., 1978; De Wit, 1978).

Nematode damage has considerable effects on root activity (Evans et al., 1975; Evans et al., 1977; Evans and Franco, 1979; Evans, 1982b), and thus possibly on the

Neth. J. Pl. Path. 91 (1985) 
functional balance between shoot and root activity (Evans, 1982c). The second important effect of invasion is that it alters the timing of various events in crop development: it stimulates senescence (Evans, 1982c), perhaps through its effect on the abscisic acid levels in the plant (Evans et al., 1981; Evans, 1982b); and, perhaps more costly, it may postpone tuber induction (Seinhorst, 1979). The model is to be extended to include these effects when they can be reliably quantified.

Curiously, these weaknesses in this particular model illustrate one of the main strengths of the approach: its structured, mechanistic nature means that even at an early stage in its development questions are raised which demand precise, quantitative answers, e.g., how many free larvae can invade a section of root without causing necrosis? By how much does each parasitic larva reduce the water uptake efficiency? The construction of such a model is thus also the construction of a precise framework for future research. The suggestion of research priorities becomes even more specific during the later stage of the process, when the model is simplified using the results of a sensitivity analysis. This examines the effect of each variable on the behaviour of the system, thus showing which variables are the most important and which others can be ignored.

The second great strength of the dynamic simulation approach becomes apparent only after the model is able accurately to describe the system. At this point it becomes possible to perform experiments on the model, thus saving the considerable efforts involved in preliminary experiments on the real system. Such imaginary experiments can rule out suggested control methods without the time and expense of field trials, thus allowing the field workers to concentrate their efforts on testing the most promising methods. Throughout the process of construction, quantification, validations and use of the model, however, it is essential to remember that the model is only a simplified abstraction of the real system. Imaginary experiments, while an extremely powerful tool for orienting research, can never be a substitute for true empiricism. The two processes, modelling and experimentation, must move in tandem, each stimulating and redirecting the other.

\section{Acknowledgements}

This work has benefited greatly from the assistance, encouragement and constructive criticisms of Mr P.G.M. Akkermans, Mr. B.H.J. van Amersfoort, Ir Monique L.H. Calon, Dr K. Evans, Ir R. Groendijk, Ing. H.D.J, van Heemst, Dr Ir H. Hoestra, Mr R. Janssen, Dr F.G.W. Jones, Mrs H.H. van Laar, Ir A. Mulder, Dr J.N. Perry, Ir J.C. Seidell, Dr Ir J.W. Seinhorst, Dr D. Thiery, Dr Ir J. Vos, Prof. Dr A. van der Wal, Dr W.J. van der Weijden, Mr W. van de Werf and Mr F. Zoon. S.A. Ward was funded by the Royal Society (London).

\section{Samenvatting}

Constructie en voorlopige evaluatie van een simulatiemodel van de populatiedynamica van het àardappelcysteaaltje, Globodera pallida

Op dit moment vindt bestrijding van het aardappelcysteaaltje, Globodera rostochiensis en G. pallida voornamelijk plaats m.b.v. nematiciden, resistente rassen en 
vruchtwisseling. In Nederland worden deze drie bestrijdingswijzen gecombineerd in een stelsel van strakke voorschriften die wettelijk zijn vastgelegd. Problemen met resistentie en teruglopende effectiviteit in de bestrijding maken de ontwikkeling van een flexibele aanpak noodzakelijk. Teneinde deze regeling te ontwikkelen is het nodig te beschikken over een inzicht in de populatiedynamica van het aardappelcysteaaltje en de gevolgen van hoge dichtheden voor de opbrengst. Op grond van literatuurgegevens en niet gepubliceerde experimentele gegevens van diverse onderzoekers is een model geconstrueerd waarmee het populatieverloop kan worden berekend en waarmee de schade aan het gewas kan worden geschat.

Vele relaties in dit model berusten op voorlopige schattingen, omdat nadere kwantitatieve gegevens ontbreken. Niettemin zijn de uitkomsten van het eenvoudige model zodanig, dat voorspellingen met het model mogelijk lijken. Zowel de relatie tussen initiële nematodendichtheid en de jaarlijkse vermenigvuldigingssnelheid, als het effect van de nematodendichtheid op de knolopbrengst worden goed gesimuleerd. Ook het effect van vroeg oogsten en de veranderingen in aantallen gedurende het seizoen worden goed gesimuleerd.

Hoewel het model redelijke uitkomsten geeft en daarmee bruikbaar lijkt voor voorspelling en gevoeligheidsanalyse zijn er nog een aantal punten die verbetering behoeven. Zo dient het groeimodel voor de aardappel te worden aangevuld met een waterbalans, opdat situaties. waarin watertekort optreedt goed kunnen worden behandeld. Voorts dient nauwkeuriger informatie over de fysiologische effecten van de nematoden op wortelactiviteit te worden geïntroduceerd. Deze verbeteringen vergen een goede synthese tussen voortgaande modelbouw en experimenteel werk. De resultaten van het nu geconstrueerde model tonen reeds aan hoe vruchtbaar deze samenwerking kan zijn.

\section{References}

Allen, E.J. \& Scott, R.K., 1980. An analysis of growth of the potato crop. J. agric. Sci. Camb. 94: 583-606.

Asfary, A.F., Wild, A. \& Harris, P.M., 1983. Growth, mineral nutrition and water use by potato crops. J. agric. Sci. Camb. 100: 87-101.

Berryman, A.A. \& Pienaar, L.V., 1974. Simulation: a powerful method for investigating the dynamics and management of insect populations. Env. Ent. 3: 199-207.

Brande, J. van den \& Herde, J. d', 1964. Phenological control of the potato root eelworm (Heterodera rostochiensis Woll.). Nematologica 10: 25-28.

Bridgeman, M.R. \& Kerry, B.R., 1980. The sex ratios of cyst-nematodes produced by adding single second-stage juveniles to host roots. Nematologica 26: 209-213.

Brouwer, R., 1962. Nutritive influences on the distribution of dry matter in the plant. Neth. J. agric. Sci. 10: 399-408.

Chitwood, B.G. \& Buhrer, E.M., 1946. The life-history of the golden nematode of potatoes, Heterodera rostochiensis Wollenweber, under Long Island, New York, conditions. Phytopathology 36: 180-189.

Clarke, A.J. \& Perry, R.N., 1977. Hatching of cyst-nematodes. Nematologica 23: 350-368.

Davidson, R.L., 1969a. Effect of root/leaf temperature differentials on root/shoot ratios in some pasture grasses and clover. Ann. Bot. 33: 561-569.

Davidson, R.L., 1969b. Effects of soil nutrients and moisture on root/shoot ratios in Lolium perenne L. and Trifolium repens L. Ann. Bot. 33: 571-577.

Neth. J. Pl. Path. 91 (1985) 
Ellenby, C., 1954. Environmental determination of the sex ratio of a plant parasite nematode. Nature 174: 1016-1017.

Ellenby, C., 1955. The seasonal response of the potato-root eelworm Heterodera rostochiensis Wollenweber: emergence of larvae throughout the year from cysts exposed to different temperature cycles. Ann. appl. Biol. 43: 1-11.

Ellenby, C. \& Smith, L., 1967. Emergence of larvae from new cysts of the potato root eelworm, Heterodera rostochiensis. Nematologica 13: 273-278.

Ellenby, C. \& Smith, L., 1975. Temperature adaption in the potato cyst nematode, Heterodera rostochiensis. Nematologica 21: 114-115.

El Nadi, A.M., Brouwer, R. \& Locher, J.Th., 1969. Some response of the root and the shoot of V'icia faba plants to water stress. Neth. J. agric. Sci. 17: 133-142.

Evans, K., 1969. Changes in a Heterodera rostochiensis population through the growing season. Ann. appl. Biol. 64: 31-41.

Evans, K., 1982a. Effects of host variety, photoperiod and chemical treatments on hatching of Globodera rostochiensis. J. Nematol. 14: 203-207.

Evans, K., 1982b. Water use, calcium uptake and tolerance of cyst-nematode attack in potatoes. Potato Res. 25: 71-88.

Evans, K., 1982c. Effects of infestation with Globodera rostochiensis (Wollenweber) Behrens Rol on the growth of four potato cultivars. Crop Protection 1: 169-179.

Evans, K., 1983. Hatching of potato cyst nematodes in root diffusates collected from twenty-five potato cultivars. Crop Protection 2: 97-103.

Evans, K. \& Franco, J., 19\%9. Tolerance to cyst-nematode attack in commercial potato cultivars ans some possible mechanisms for its operation. Nematologica 25: 153-162.

Evans, K., Greet, D.N., Minter, K. \& Wilson, J., 1981. Tolerance by potatoes to cyst nematode attack. Rep. Rothamsted Exp. Station 1980. Pt. 1: 155.

Evans, K., Parkinson, K.J. \& Trudgill, D.L., 1975. Effects of potato cyst-nematodes on potato plants. III. Effects on water relations and growth of a resistant and susceptible variety. Nematologica 21: 273-280.

Evans, K., Trudgill, D.L. \& Brown, N.J., 1977. Effects of potato cyst-nematodes on potato plants. V. Root system development in lightly and heavily infested susceptible and resistant varieties and its importance in water and nutrient uptake. Nematologica 23: 153-164.

Fenwick, D.W., 1951. The effect of temperature on development of the potato-root eelworm, Heterodera rostochiensis. Ann. appl. Biol. 38: 615-617.

Ferris, J.M., 1957. Effect of soil temperature on the life cycle of the golden nematode in host and non-host species. Phytopathology 47: 221-230.

Ferris, J.M., 1976. Development of a computer-simulation model for a plant-nematode system. J. Nematol. 8: 255-263.

Foot, M.A., 1978. Temperature responses of three potato cyst-nematode populations from New Zealand. Nematologica 24: 412-417.

Forrest, J.M.S. \& Perry, R.N., 1980. Hatching of Globodera pallida after brief exposure to potato root diffusate. Nematologica 26: 130-132.

Franco, J., 1979. Effect of temperature on hatching and multiplication of potato cystnematodes. Nematologica 25: 237-244.

Franco, J., Jatala, P. \& Bocangel, M., 1981. Efficiency of Paecilomyces lilacinus as a biocontrol agent of Globodera pallida. J. Nematol. 13: 438-439.

Gandar, P.W. \& Tanner, C.B., 1976. Leaf growth, tuber growth and water potential in potatoes. Crop Sci. 16: 534-538.

Goswamy, B.K. \& Rumpenhorst, H.J., 1978. Association of an unknown fungus with potato cyst nematodes, Globodera rostochiensis and G. pallida. Nematologica 24: 251-256.

Grainger, J., 1962. Host, parasite and man in crop disease. Meded. Landb.hogesch. Gent 27: $671-702$. 
Groendijk, R., 1984. Kan grondontsmetting in de intensieve aardappelteelt selektiever? Landbouwkundig Tijdschrift 96(4): 28-32.

Hague, N.G.M., 1978. Nematodes the unseen enemy: a guide to nematode damage. Du Pont de Nemours, Geneva.

Hesling, J.J., 1961. Heterodera rostochiensis Woll. 1923 on Solanum demissum - a population study: Ann. appl. Biol. 49: 350-359.

Hoestra, H. \& Harshagen, H., 1981. Effect of soil treatment with softwood bark on Globodera rostochiensis. Med. Fac. Landbouww. Rijksuniv. Gent. 46: 703-705.

Hominick, W.M., 1979. Selection for hatching at low temperature in Globodera rostochiensis by continuous cultivation of early potatoes. Nematologica 25: 322-332.

Huijsman, C.A., Klinkenberg, C.H. \& Ouden, H. den, 1969. Tolerance to Heterodera rostochiensis Woll. among potato varieties and its relation to certain characteristics of root anatomy. Eur. Potato J. 12: 134-147.

Hijink, M.J., 1972. An integrated approach in the control of potato root eelworm. EPPO Bull. 7: 41-48.

Jatala, P., Kaltenbach, R. \& Bocangel, M., 1979. Biological control of Meloidogyne incognita acrita and Globodera pallida on potatoes. J. Nematol. 11: 303.

Jones, F.G.W., 1966. The population dynamics and population genetics of the potato cystnematode Heterodera rostochiensis Woll. on susceptible and resistant potatoes. Rep. Rothamsted. Exp. Station 1965, 301-316.

Jones, F.G.W., 1974a. Control of nematode pests, background and outlook for biological control. Pp 249-268. In; D. Price J $\delta$ nes \& M.E. Solomon (Eds), Biology in pest and disease control. Blackwell, Oxford.

Jones, F.G.W., 1974b. Host parasite relationships of potato cyst-nematodes: a speculation arising from the gene-for-gene hypothesis. Nematologica 20: 437-443.

Jones, F.G.W., 1975. Accumulated temperature and rainfall as measures of nematode development and activity. Nematologica 21: 62-70.

Jones, F.G.W., 1983. Weather and plant parasitic nematodes. EPPO Bull. 13: 103-110.

Jones, F.G.W. \& Kampton, R.A., 1978. Population dynamics, population models and integrated control. Pp. 333-361. In: J.F. Southey (Ed.), Plant nematology. HSMO, London.

Jones, F.G.W., Kempton, R.A.\& Perry, J.N., 1978. Computer simulating and population models for cyst-nematodes. (Heteroderidae: Nematoda). Nematropica 8: 36-56.

Jones, F.G.W. \& Parrott, D.M., 1969. Population fluctuations of Heterodera rostochiensis Woll. when susceptible potato varieties are grown continuously. Ann. appl. Biol. 63: 175-181.

Jones, F.G.W., Parrott, D.M. \& Perry, J.N., 1981. The gene-for-gene relationship and its significance for potato cyst nematodes and their solanaceous hosts. Pp 23-36: In B.M. Zuckerman \& R.A. Rohde (Eds), Plant parasitic nematodes. Vol. III, Academic Press, New York.

Jones, F.G.W., Parrott, D.M. \& Ross, G.J.S., 1967. The population genetics of the potato cystnematode, Heterodera rostochiensis: mathematical models to simulate the effects of growing eelworm-resistant potatoes bred from Solanum tuberosum ssp andigena. Ann. appl. Biol. 60: $151-171$.

Jọnes, F.G.W. \& Perry, J.N., 1978. Modelling populations of cyst-nematodes (Nematoda: Heteroderidae). J. appl. Ecol. 15: 349-371.

Kerry, B.R., 1980. Biocontrol: fungal parasites of female cyst-nematodes. J. Nematol. 12: 253-259.

Keulen, H. van, Penning de Vries, F.W.T. \& Drees, E.M., 1982. A summary model for crop growth. Pp. 87-97. In: F.W.T, Penning de Vries \& H.H. van Laar (Eds), Simulation of plant growth and crop production. Simulation Monographs. Pudoc, Wageningen.

Kort, J., Ross, H., Rumpenhorst, H.J. \& Stone, A.R., 1977. An international scheme for identifying and classifying pathotypes of potato cyst-nematodes Globodera rostochiensis and $G$.

Neth. J. Pl. Path. 91 (1985) 
pallida. Nematologica 23: 333-339.

Langeslag, M., Mugniery, D. \& Fayet, G., 1982. Développement embryonnaire de Globodera rostochiensis et $G$. pallida en fonction de la temperature, en conditions contrôlées et naturelles. Revue Nématol. 5: 103-109.

Mugniery, D., 1976. Etablissement d'un modèle de dynamique de population d'Heterodera pallida (Stone): applications à un cas pratique de lutte intégrée. Ann. Zool. Ecol. anim. 8: 315-329.

Mugniery, D., 1978a. Vitesse de de développement, en fonction de la température, de Globodera rostochiensis et $G$. pallida (Nematoda: Heteroderidae). Rev. Nématol. 1: 3-12.

Mugniery, D., 1978b. Lutte culturale contre les nématodes à kyste de la pomme de terre Globodera rostochiensis (Wollenweber) et $G$. pallida (Stone) et perspectives de lutte intégrée. Ann. Zool. Ecol. anim. 10: 187-203.

Mugniery, D., 1982. Diversités régionales d'application de lutte intégrée en culture de pommes de terre en fonction de la variabilité des populations de nématodes à kystes. Agronomie 2: 629-640.

Mugniery, D. \& Fayet, G., 1981. Détermination du sexe chez Globodera pallida Stone. Rev. Nématol. 4: 41-45.

Mulder, A., 1978. Is het verantwoord om een grondontsmetting met Metamnatrium of Dichloorpropeen uit te voeren in aardappelland? Onderzoek 1978: 127-137. Stichting Akkerbouwproefboerderijen, Emmen.

Mulder, A., 1981. Pathotypenontwikkeling van de aardappelcystenaaltjes in het fabrieksaardappelgebied. Onderzoek 1981: 182-185. Stichting Interprovinciaal Onderzoekcentrum voor de Akkerbouw, Emmen.

Neye, W. von, Stelter, H., Herold, M. \& Ihle, W., 1964. Untersuchungen über die Veränderungen von Nematodenpopulationen (Heterodera rostochiensis Woll.) Typ A beim praktischen Feldanbau von Nematoden resistenten Kartoffeln (Sol. andigenum $x$ Sol. tuberosum). Nachrichtenbl. Dt. Pflanzenschutzdienst (Berlin) 18: 64-65.

Onstad, D.W.R., Rabbinge, R. \& Rossing, W.A., 1983. Improvement of a wheat pest management system. Proc. 10th Int. Cong. Plant Prot.

Oostenbrink, M., 1966. Major characteristics of the relation between nematodes and plants. Med. Landbouwhogeschool Wageningen ff5: 1-45.

Ouden, H. den, 1960a. Periodicity in spontaneous hatching of Heterodera rostochiensis in the soil. Nematologica (Suppl. II): 101-105.

Ouden, H. den, 1960b. A note on parthenogenesis and sex determination in Heterodera rostochiensis Woll. Nematologica 5: 215-216.

.Ouden, H. den, 1963. A comparison between the use of free and encysted eggs in hatching and pot experiments with Heterodera rostochiensis. Nematologica 9: 225-230.

Ouden, H. den, 1969. The influence of volunteer potatoes in oats on the population density of Heterodera rostochiensis. Nematologica 13: 325-335.

Parrott, D.M., 1979. The gene-for-gene relationship. Rep. Rothamsted Exp. Stn. 1978. Pt. 1: 182.

Parrott, D.M., 1981. Evidence for gene-for-gene relationships between resistance gene $\mathrm{H}_{1}$ from Solanum tuberosum ssp andigena and a gene in Globodera rostochiensis, and between $\mathrm{H}_{2}$ from S. multidissectum and a gene in G. pallida. Nematologica 27: 372-384.

Perry, J.N. \& Jones, F.G.W., 1981. Simulations of population models for cyst-nematodes: applications in agriculture. Proc. AMS81, 1st ASTED conference, Lyon: AMSE, Vol. V: 15-18.

Perry, R.N. \& Beane, J., 1982. The effect of brief exposures to potato root diffusate on the hatching of Globodera rostochiensis. Revue Nématol. 5: 221-224.

Perry, R.N., Hodges, J.A. \& Beane, J., 1981. Hatching of Globodera rostochiensis in response to potato root diffusate persisting in soil. Nematologica 27: 349-352.

Rabbinge, R., 1976. Biological control of fruit tree red spider mite. Simulation Monograph, 
Pudoc, Wageningen, the Netherlands, $277 \mathrm{pp}$.

Raeuber, A., \& Stelter, H., 1970. Die Endverseuchung in Abhängigkeit von der Anfangspopulation bei Heterodera rostochiensis Woll. Biol. Zentralbl. 89: 87-91.

Ross, G.J.S. \& Trudgill, D.L., 1969. The effect of population density on the sex-ratio of Heterodera rostochiensis: a two-dimensional model. Nematologica 15: 601-607.

Schick, R. von \& Stelter, H., 1963. Wert und Bedeutung der nematodenresistenten Kartoffeln sowie einige Bemerkungen zu deren Anbau. Nachrichtenbl. Dt. Pflanzenschutsdienst (Berlin) 17: 75-79.

Seinhorst, J.W., 1965. The relation between nematode density and damage to plants. Nematologica 11: 137-154.

Seinhorst, J.W., 1967. The relationship between population increase and population density in plant parasitic nematodes. II. Sedentary nematodes. Nematologica 13: 157-171.

Seinhorst, J.W., 1968. The relationship between population increase and population density in plant parasitic nematodes. V. Influence of damage to the host on multiplication. Nematologica 13: 481-492.

Seinhorst, J.W., 1973. The relation between nematode distribution in a field and loss in yield at different average nematode densities. Nematologica 19: 421-427.

Seinhorst, J.W.., 1979. Nematodes and growth of plants, formalization of the nematode plant system. Pp. 231-256. In: F. Lamberti \& C.E. Taylor (Eds), Root knot nematodes (Meloidogyne species) systematics, biology and control. Academic Press, New York.

Seinhorst, J.W., 1982. Achtergronden van aaltjesbestrijding (3). Bedrijfsontwikkeling 13: 494-500.

Seinhorst, J.W., 1983. The relationship in field experiment between population density of Globodera rostochiensis before planting potatoes and yield of potato tubers. Nematologica (in press).

Seinhorst, J.W. \& Ouden, H. den, 1971. The relation between density of Heterodera rostochiensis and growth and yield of two potato varieties. Nematologica 17: 347-369.

Steckel, J.R.A. \& Gray, D., 1979. Drought tolerance in potatoes. J. agric. Sci. Camb. 92: 375-381.

Stelter, G., 1970. Eine populationsdynamische Studie über Typ A des Kartoffelnematoden (Heterodera rostochiensis Wollenweber). Nachrichtenbl. Dt. Pflanzenschutzdienst (Berlin) 24: 27-31.

Stone, A.R., Fuller, J.M. \& Howard, H.W., 1979. The presence of pathotype Pa2 of Globodera pallida in the United Kingdom. Pl. Path. 28: 134-137.

Stone, A.R. \& Parrott, D.M., 1980. Morphology of potato cyst-nematodes. Rep. Rothamsted Exp. Stn. 1979. Pt 1: 142.

Stone, A.R. \& Turner, S.J., 1981. Cyst nematode biology: pathotypes. Rep. Rothamsted Exp. Stn. 1980. Pt 1: 156-157.

Stone, L.E.W., Webley, D.P., Lewis, S. \& Evans, E.B., 1973. The persistance of potato cyst eelworm (Heterodera pallida Stone) under different non-host regimes. Pl. Path. 22: 181-183.

Thornley, J.H.M. \& Hesling, J.J., 1972. Models describing sex ratio data in Heterodera rostochiensis. 1. Environmentally determined sex. Nematologica 18: 563-570.

Trudgill, D.L., 1967. The effect of environment on sex determination in Heterodera rostochiensis. Nematologica 13: 263-272.

Trudgill, D.L. \& Cotes, L.M. 1983a. Differences in the tolerance of potato cultivars to potato cyst nematodes (Globodera rostochiensis and $G$. pallida) in field trials with and without nematicides. Ann. appl. Biol. 102: 373-384.

Trudgill, D.L. \& Cotes, L.M., 1983b. Tolerance of potato cyst nematodes (Globodera rostochiensis and $G$. pallida) in relation to the growth and efficiency of the root system. Ann. appl. Biol. 102: 385-397.

Turner, S.J. \& Stone, A.R., 1981. Hatching of potato cyst nematodes (Globodera rostochiensis and G. pallida) in root exudates of Solanum vernei hybrids. Nematologica 27: 315-318.

Neth. J. Pl. Path. 91 (1985) 
Webley, D.P. \& Jones, F.G.W., 1981. Observations on Globodera pallida and G. rostochiensis on early potatoes. Pl. Path. 30: 217-224.

Whitehead, A.G., 1977. Vertical distribution of potato, beet and pea cyst nematodes in some heavily infested soils. Pl. Path. 26: 85-90.

Weijden, W.J. van der, 1981. Vraagtekens bij de grondontsmetting in de aardappelteelt. Landbouwk. Tijdschrift. 93: 205-211.

Wit, C.T. de, 1978. Een elementair model van gewasgroei. Landbouwk. Tijdschr. 90: 275-281.

Wit, C.T. de et al., 1978. Simulation of assimilation, respiration and transpiration of crops. Simulation Monographs. Pudoc, Wageningen.

Wit, C.T. de \& Goudriaan, J., 1978. Simulation of ecological processes. Simulation Monographs, Pudoc. Wageningen.

Wit, C.T. de \& Keulen, H. van, 1972. Simulation of transport processes in soils. Simulation Monographs, Pudoc, Wageningen.

Wit, C.T. de \& Rabbinge, R., 1979. Systems analysis and dynamic simulation. EPPO Bull. 9: $149-153$ 